\title{
THE USE OF ANION GEOCHEMISTRY IN MAPPING GROUNDWATER FACIES IN THE PORT HARCOURT AREA OF THE NIGER DELTA, NIGERIA.
}

\section{P. AMADI ABI-BEZAM AND C.E., EGBOKA BONIFACE.}

(Received 06 July 2009; Revision Accepted 26, April 2010)

\begin{abstract}
The groundwater system of the Port Harcourt area is home to three anion facies, the $\mathrm{Cl}-\mathrm{SO}_{4}$, the $\mathrm{Cl}_{-} \mathrm{SO}_{4}-\mathrm{HCO}_{3}$ and the $\mathrm{HCO}_{3}-\mathrm{Cl}-\mathrm{SO}_{4}$. The first two types exist in both shallow - and deep - groundwater environments while the third is restricted to the deep environment. Although there are natural intermittent and, in some cases, continuous interactions between shallow and deep groundwaters, this paper establishes that the quality and facies types of the groundwaters are not exactly alike. 28 groundwater samples (12 from hand-dug wells; 16 from boreholes) were analysed for $\mathrm{Cl}, \mathrm{SO}_{4}, \mathrm{HCO}_{3}$ and $\mathrm{CO}_{3}$. The concentration levels of $\mathrm{SO}_{4}{ }^{2-}$ were analysed using the $\mathrm{HACH}$ Spectrophotometer equipment, model $\mathrm{No} \mathrm{DR} / 2000$ while those of $\mathrm{Cl}^{-}, \mathrm{CO}_{3}{ }^{2-}$ and $\mathrm{HCO}_{3}{ }^{-}$were by titrimetric method, using the Titro Process Dosimat 665 equipment. The results indicate that, for the hand-dug wells, $\mathrm{SO}_{4}{ }^{2-}$ levels ranged from $0.00 \mathrm{mg} / \mathrm{l}$ to $67.0 \mathrm{mg} / \mathrm{l}$ with an average of $16.5 \mathrm{mg} / \mathrm{l} ; \mathrm{HCO}_{3}{ }^{-}$from 12.2 to 36.6 with an average of 15.25 , while $\mathrm{Cl}^{-}$ ranged from 11.332 to 121.905 with an average of $41.22 \mathrm{mg} / \mathrm{l}$. No $\mathrm{CO}_{3}{ }^{2-}$ was detected in all the samples. For the borehole samples, the respective figures for $\mathrm{SO}_{4}{ }^{2-}, \mathrm{HCO}_{3}{ }^{-}$and $\mathrm{Cl}^{-}$are 0.00 to 33.0 with an average of $2.13 ; 12.2$ to 24.4 with an average of 12.96 , and 5.490 to 72.306 with an average of $17.037 \mathrm{mg} / \mathrm{l}$. Again, no $\mathrm{CO}_{3}{ }^{2-}$ was detected. The total absence of $\mathrm{CO}_{3}{ }^{2-}$ conforms with the relatively high acidity of the groundwater environment of the Port Harcourt Area; and the diminutive level of $\mathrm{SO}_{4}{ }^{2-}$, is associated with the effect of the bacteria catalysed reduction of the ion. This absence of some ions and the low levels in others do affect the number and type of mappable facies in groundwater systems. With the results obtained, the paper notes that:
\end{abstract}
The shallow groundwater environment embedded less number of mappable facies than the deep groundwater environment;
Facies sequences mapped are tending towards the composition of seawater; and concludes that the existence of different groundwater facies is an evidence that groundwater encounters strata of different mineralogical compositions along its flow path.

\section{KEY WORDS: Anion facies, Hand-dug well, Mappable, Acidity, Sulphate reduction.}

\section{INTRODUCTION}

Hydrogeological practice in the Port Harcourt area of the Niger Delta has centred mainly on drilling for water supply. Details of water quality are rare except for some scanty qualitative details that appear in Amajor (1991), Etu-Efeotor (1981), Abibo (1988) and Akujieze et al. (2003). There is hitherto no literature on the aspect of groundwater facies for the Port Harcourt region.

\section{Hydrochemical Facies}

Facies are identifiable parts of different nature belonging to any genetically related body or system. Hydrochemical facies are distinct zones that have cation and anion concentrations describable within defined composition categories. Domenico (1972) notes that although specific details concerning methodology vary somewhat, the facies are studied in much the same manner as lithofacies in geology, with Piper's (1944) trilinear diagram, or some slight modification, used to identify the various chemical types. The areal distribution of constituents is shown by fence diagrams, hydrochemical facies can be studied in terms of anions, or cations, or both. These various options of study may be in consideration for the scope of the research involved or of the possible unavailability of relevant equipment or both. For example, Chebotarev (1955) used anion species only and developed his well-known sequence which states that all groundwaters tend to evolve chemically toward the composition of seawater; similarly Toth (1966b) used anion facies development in mapping groundwater discharge and recharge areas in Canada; and Amadi et al.; (1989) used both anion and cation species in mapping the groundwater facies-types housed in a north-south direction of some part of the Niger Delta region. Each option defines its scope but is directed towards achieving the same objective, that is, the delineation of facies - types embedded in groundwater systems. There is no significant advantage of one ontion over the others. The thrust of this naber is 156

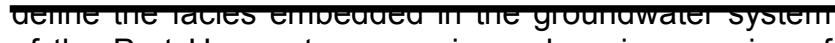
of the Port Harcourt area, using only anion species of groundwater samples from both the shallow groundwater - and deep groundwater environments of 
The study area comprises two Local Government Areas, namely, the highly industrialized Port Harcourt Local Government Area (PHALGA) and the rapidly expanding lies between latitudes $4^{\circ} 42^{\prime}$ and $4^{0} 57^{\prime} \mathrm{N}$ and longitudes $6^{\circ} 53^{\prime}$ and $7^{\circ} 08^{\prime} \mathrm{E}$ (Fig. 1) and covers an area of about $313 \mathrm{~km}^{2}$ within the Niger Delta sedimentary basin. Its

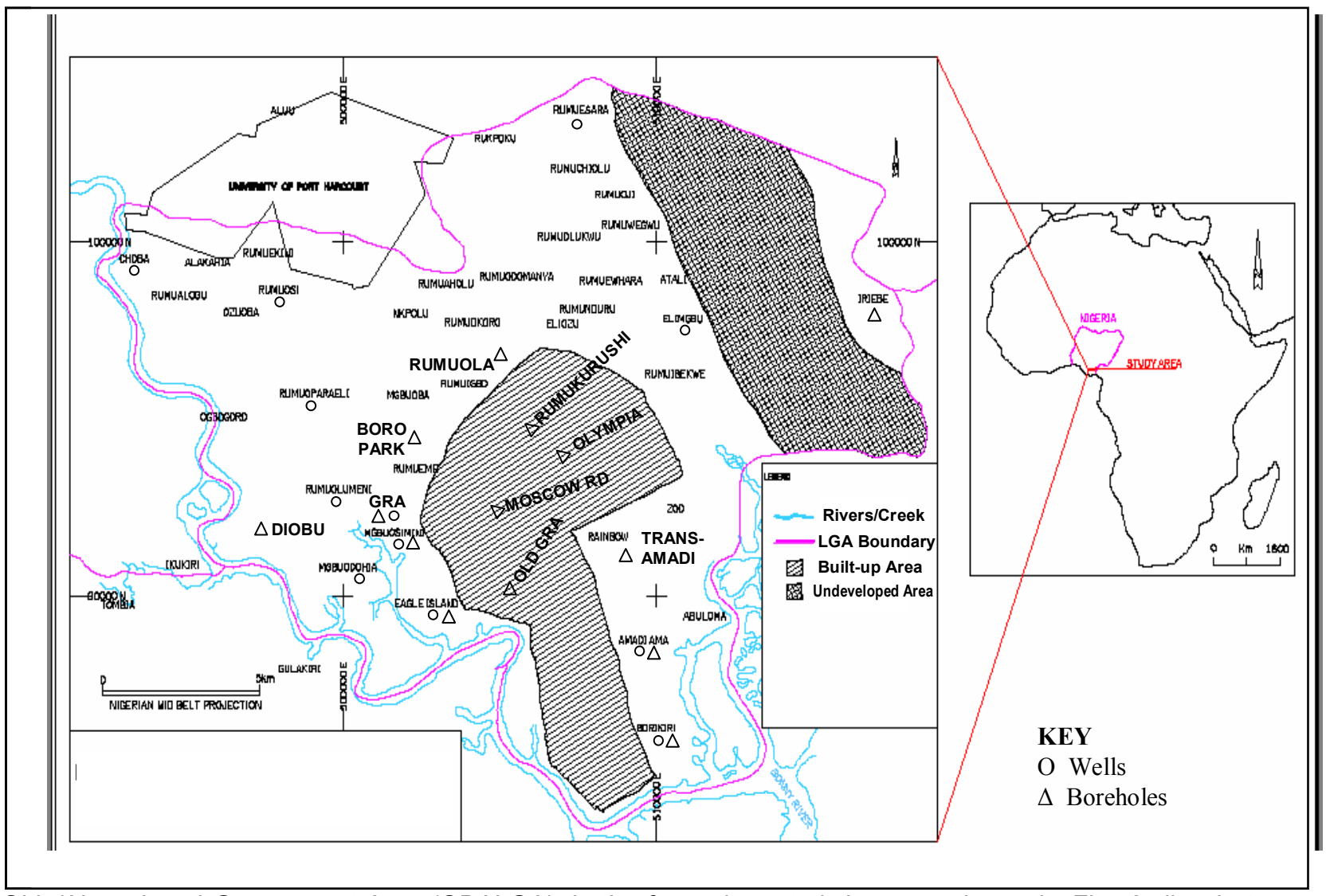

Obio/Akpor Local Government Area (OBALGA), both of which are together designated as the Port Harcourt Metropolis, or Greater Port Harcourt. The Metropolis characteristic area, shown in Fig. 2, lies between the freshwater swamp area that is seasonally flooded and the saltwater swamp area that is tidally flooded.

Fig 1: Location Map Showing Positions of Wells and Boreholes 


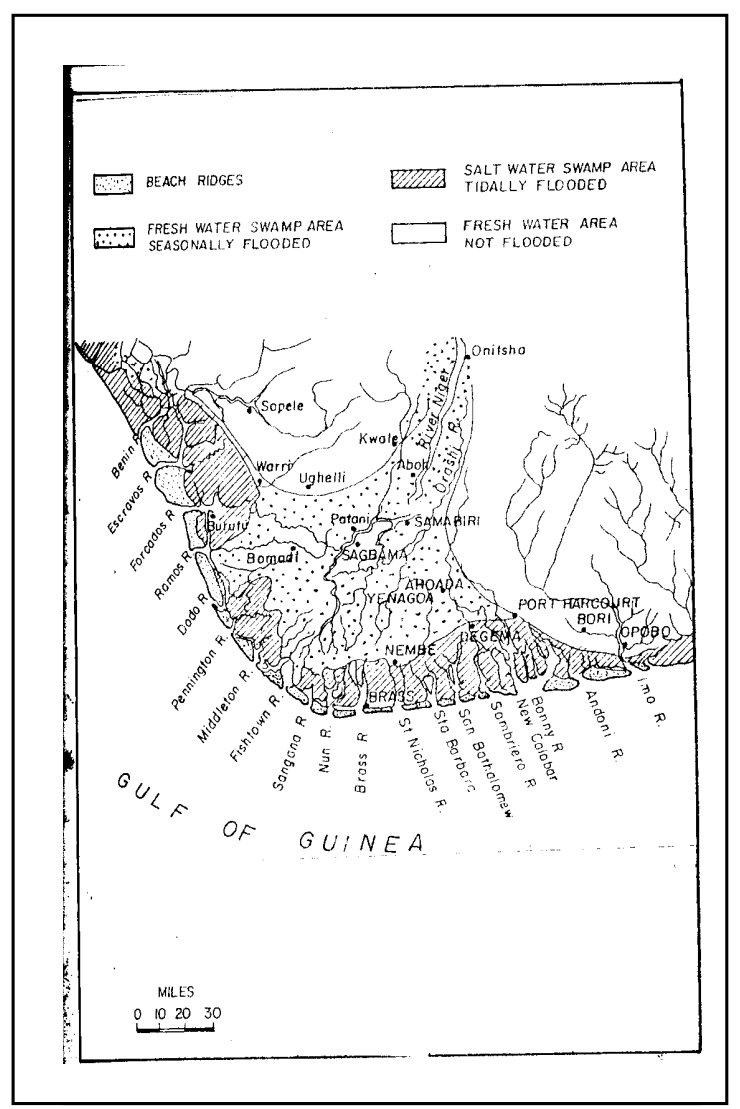

Fig.2 Characteristic Areas (NEDECO, 1959)

\section{METHODOLOGY}

Considering the objective of this work, groundwater samples were collected with scrupulously clean polyethylene plastic bottles. The samples were unacidified but were filtered through a $0.45 \mu \mathrm{m}$ pore size disposable filter paper, and collected in pre-cleaned plastic bottles. To accommodate both shallow - and deep-groundwater environments, 12 samples were collected from hand-dug wells and 16 from boreholes. The target species were $\mathrm{SO}_{4}{ }^{2-}, \mathrm{Cl}^{-}, \mathrm{CO}_{3}{ }^{2-}$ and $\mathrm{HCO}_{3}{ }^{-}$. The concentration levels of $\mathrm{SO}_{4}^{2}$ were determined using the $\mathrm{HACH}$ Spectrophotometer equipment model No. $\mathrm{DR} / 2000$ while those of $\mathrm{Cl}, \mathrm{CO}_{3}^{2}$, and $\mathrm{HCO}_{3}$ were by titrimetric method, using the Titro Process Dosimat 665 equipment. All analyses were carried out at the
Production Chemistry Laboratory of the Shell Petroleum Development Company, Nigeria Limited, Port Harcourt.

\section{STAGES IN MAPPING GROUNDWATER FACIES}

Four stages were followed in mapping the groundwater facies.

Stage (i): Results of the chemical analyses in milligrams per litre were converted to values in milliequivalents per litre.

Stage (ii): $\quad$ The resulting values of $\left(\mathrm{HCO}_{3}+\mathrm{CO}_{3}\right)$ and those of $\left(\mathrm{Cl}+\mathrm{SO}_{4}\right)$ were then respectively expressed as percentages of all anions.

Stage (iii): To define the facies, the resulting percentages were matched with the guidelines proposed by Back (1996), using the anion column in Table 7.

Stage (iv): The direction of facies change was thereafter determined by fitting the facies types into the anion diamond field of Domenico (1972), (Fig.3). 


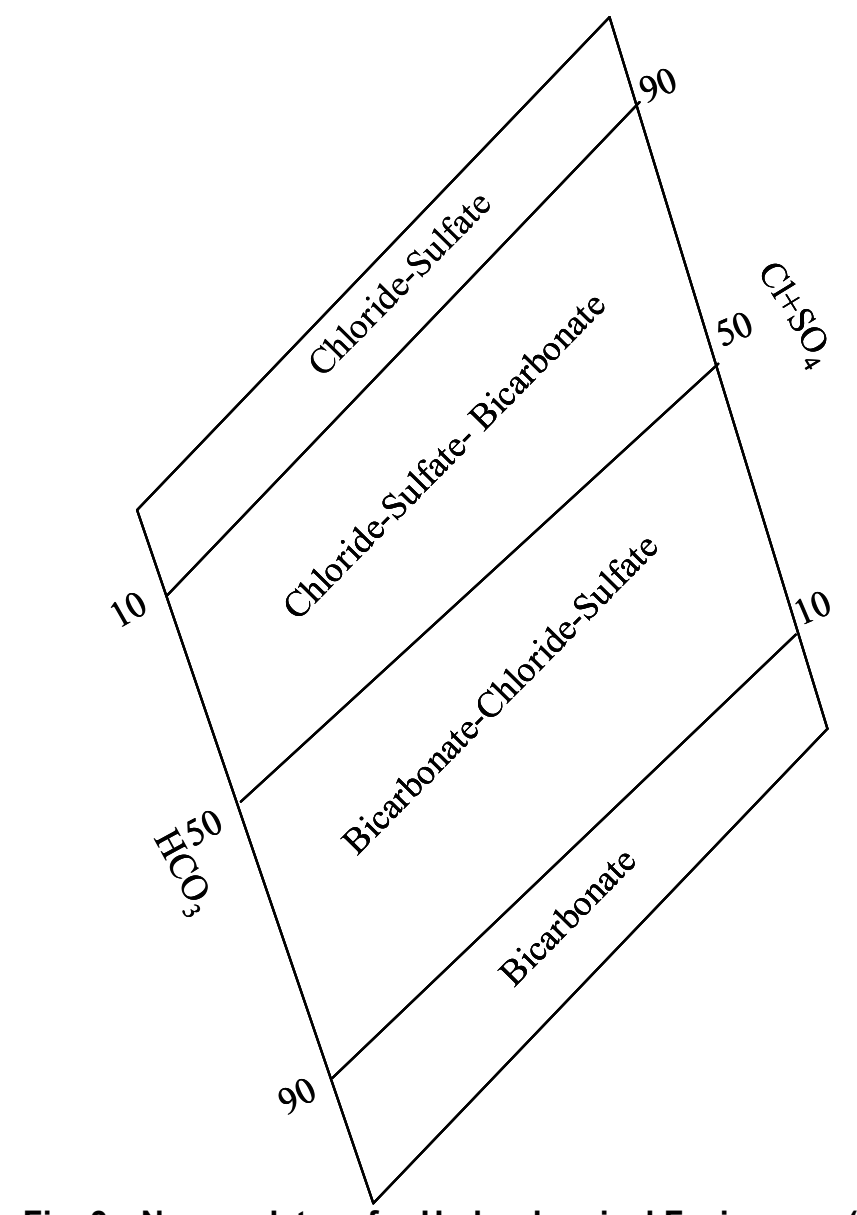

Fig. 3 Nomenclature for Hydrochemical Facies. (Domenico, 1972)

\section{RESULTS AND DISCUSSION}

The anion values of the sampled wells and boreholes are presented in Tables 1 and 2 respectively; and the results converted to values in milliequivalents per litre are presented in Tables 3 and 4 . Values of $\left(\mathrm{HCO}_{3}+\mathrm{CO}_{3}\right)$ and those of $\left(\mathrm{Cl}+\mathrm{SO}_{4}\right.$ as percentages of all anions are presented in Tables 5 and 6 . Domenico (1972) notes that hydrochemical facies can be studied in terms of anions, or cations, or both and Back (1966) gives a classification guide shown in Table 7 .

\section{Environmental Controls on the Anion Concentration Levels}

Tables 1 and 2 show that among the anions, $\mathrm{SO}_{4}{ }^{2-}$ was detected in only $50 \%$ of the 12 well samples and in only $12.5 \%$ of the 16 borehole samples. While no $\mathrm{CO}_{3}{ }^{2-}$ was detected in all 28 samples, $\mathrm{HCO}_{3}{ }^{-}$and $\mathrm{Cl}^{-}$ were detected in all. The $\mathrm{SO}_{4}{ }^{2-}$ values in the $50 \%$ of well borehole samples ranged from $1 \mathrm{mgl} / \mathrm{l}$ to $33 \mathrm{mgl} / \mathrm{l}$ with an average of $17 \mathrm{mgl} / \mathrm{l}$. The absence of $\mathrm{SO}_{4}{ }^{2-}$ in some of the samples could be attributed to sulphate - reduction, a process engineered by certain bacteria. Davis and DeWiest (1966) note that some types of sulphatereducing bacteria are found in soil horizons and that groundwater may contain less than $1 \mathrm{ppm}$ of sulphate if sulphate-reducing bacteria are active in the soil through which recharge water percolates. Domenico (1972) notes that sulphate reduction accounts for diminishing quantities of sulphate in groundwater. This process therefore controls the level of occurrence of $\mathrm{SO}_{4}{ }^{2-}$ in groundwater. For $\mathrm{CO}_{3}{ }^{2-}$, its absence in all 28 samples conforms with the relatively high acidity of the groundwater system of the Port Harcourt region. In Table 1, the $\mathrm{pH}$ range is from 4.46 to 6.30; in Table 2, the range is 4.15 to 6.14 . These $\mathrm{pH}$ values are not favourable for the formation of $\mathrm{CO}_{3}{ }^{2-}$ via the 


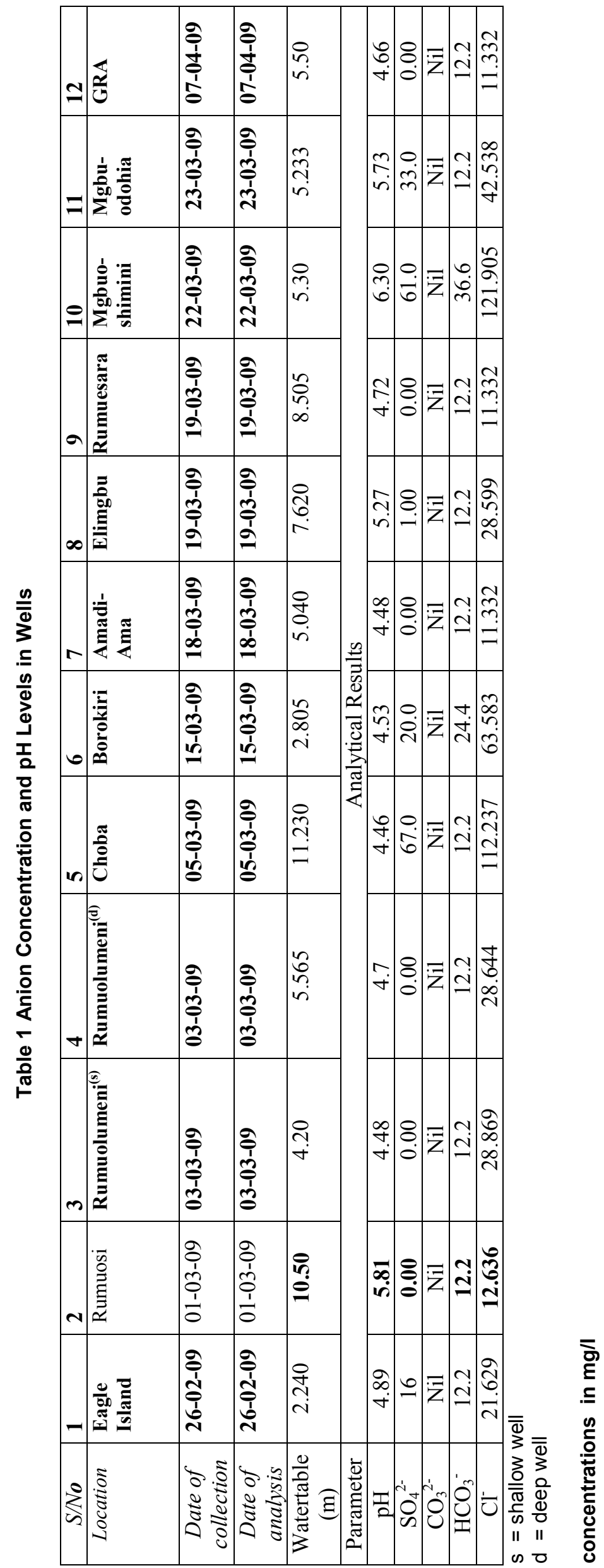




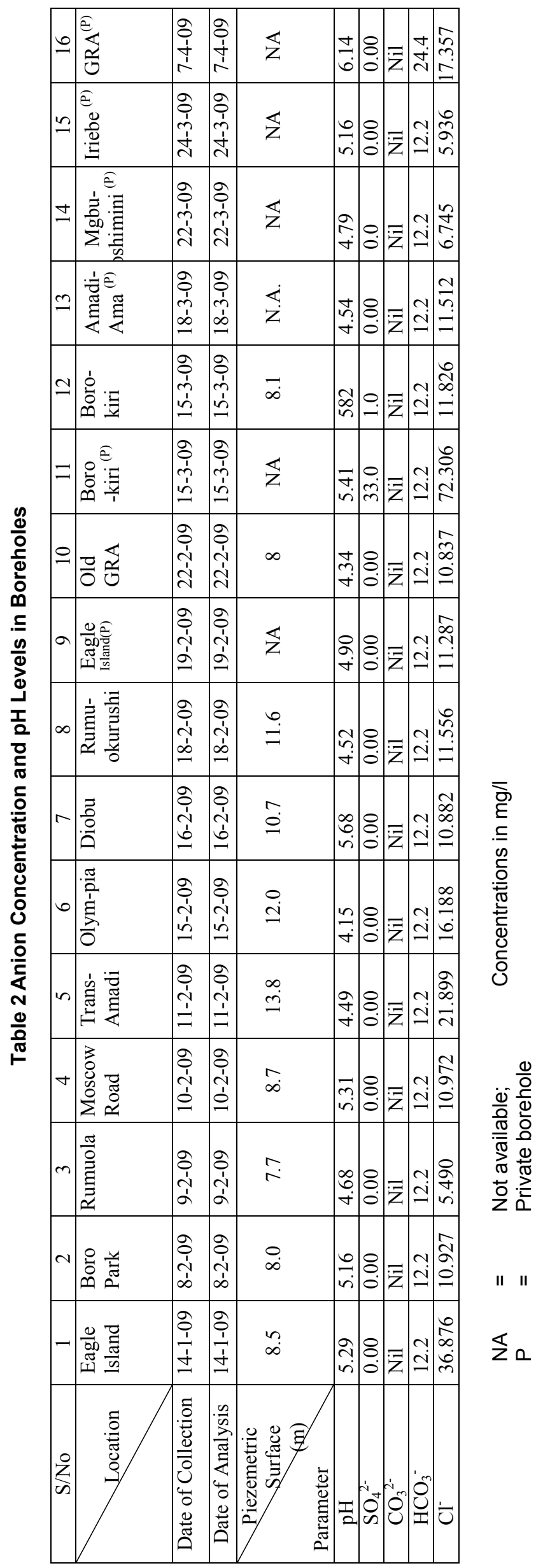


Table 3 Anions in meq/1 for Well Samples

\begin{tabular}{|c|c|c|c|c|c|c|}
\hline & $\begin{array}{l}\text { Parameter } \\
\text { Location }\end{array}$ & $\mathrm{SO}_{4}{ }^{2-}$ & $\mathrm{CO}_{3}{ }^{2-}$ & $\mathrm{HCO}_{3}^{-}$ & $\mathrm{Cl}^{-}$ & TOTAL \\
\hline 1. & Engle Island & 0.33312 & - & 0.19996 & 0.61015 & 1.14323 \\
\hline 2. & Rumuosi & - & - & 0.19996 & 0.35646 & 0.55642 \\
\hline 3. & Rumuolumeni $^{(\mathbf{s})}$ & - & - & 0.19996 & 0.81439 & 1.01435 \\
\hline 4. & Rumuolumeni $^{(\mathrm{d})}$ & - & - & 0.19996 & 0.80805 & 1.00801 \\
\hline 5. & Choba & 1.39494 & - & 0.19996 & 3.16621 & 4.76111 \\
\hline 6. & Borokiri & 0.4164 & - & 0.39992 & 1.79368 & 2.61 \\
\hline 7. & Amadi-Ama & - & - & 0.19996 & 0.31968 & 0.51964 \\
\hline 8. & Elimgbu & 0.02082 & - & 0.19996 & 0.80678 & 1.02756 \\
\hline 9. & Rumuesara & - & - & 0.19996 & 0.31968 & 0.51964 \\
\hline 10. & Mgbuoshimini & 1.27002 & - & 0.59987 & 3.43894 & 5.30883 \\
\hline 11. & Mgbuodohia & 0.68706 & - & 0.19996 & 1.20 & 2.08702 \\
\hline 12. & GRA & - & - & 0.19996 & 0.31968 & 0.51964 \\
\hline
\end{tabular}

Table $4 \quad$ Anions in meq/1 for Borehole Samples

\begin{tabular}{|c|c|c|c|c|c|c|}
\hline & $\begin{array}{l}\text { Parameter } \\
\text { Location }\end{array}$ & $\mathrm{SO}_{4}^{2-}$ & $\mathrm{CO}_{3}{ }^{2-}$ & $\mathrm{HCO}_{3}^{-}$ & $\mathrm{Cl}^{-}$ & TOTAL \\
\hline 1. & Eagle Island & - & - & 0.19996 & 1.04027 & 1.24023 \\
\hline 2. & Boro Park & - & - & 0.19996 & 0.30825 & 0.50821 \\
\hline 3. & Rumuola & - & - & 0.19996 & 0.15487 & 0.35483 \\
\hline 4. & Moscow Road & - & - & 0.19996 & 0.30952 & 0.50948 \\
\hline 5. & Trans-Amadi & - & - & 0.19996 & 0.61777 & 0.81773 \\
\hline 6. & Olympia & - & - & 0.19996 & 0.45666 & 0.6566 \\
\hline 7. & Diobu & - & - & 0.19996 & 0.30698 & 0.50685 \\
\hline 8. & Rumukurushi & - & - & 0.19996 & 0.32599 & 0.52595 \\
\hline 9. & Eagle Island ${ }^{(P)}$ & - & - & 0.19996 & 0.31841 & 0.51837 \\
\hline 10. & Old GRA & - & - & 0.19996 & 0.30571 & 0.50567 \\
\hline 11. & Borokiri $^{(P)}$ & 0.68706 & - & 0.19996 & 2.03975 & 2.92677 \\
\hline 12. & Borokiri $^{(P)}$ & 0.02082 & - & 0.19996 & 0.33361 & 0.55439 \\
\hline 13. & Amadi-Ama ${ }^{(P)}$ & - & - & 0.19996 & 0.32475 & 0.52471 \\
\hline 14. & Mgbuoshimini $^{(P)}$ & - & - & 0.19996 & 0.190276 & 0.390236 \\
\hline 15. & Iriebe $^{(P)}$ & - & - & 0.19996 & 0.167455 & 0.36742 \\
\hline 16. & $\mathrm{GRA}^{(P)}$ & - & - & 0.3992 & 0.48964 & 0.88884 \\
\hline
\end{tabular}

Table 5 Values of $\left(\mathrm{HCO}_{3}+\mathrm{CO}_{3}\right)$ and of $\left(\mathrm{Cl}+\mathrm{SO}_{4}\right)$ as percentages of all Anions for Well Samples

\begin{tabular}{|l|l|c|c|}
\hline & Location Parameter & $\mathbf{H C O}_{3}+\mathbf{C O}_{3}$ & $\mathbf{C l}+\mathbf{~ S O}_{4}$ \\
\hline 1. & Engle Island & 17.49 & 82.509 \\
\hline 2. & Rumuosi & 35.9368 & 64.063 \\
\hline 3. & Rumuolumeni ${ }^{(\mathbf{s})}$ & 19.713 & 80.287 \\
\hline 4. & Rumuolumeni ${ }^{(\mathbf{d})}$ & 19.837 & 80.163 \\
\hline 5. & Choba & 4.1998 & 95.896 \\
\hline 6. & Borokiri & 15.322 & 84.677 \\
\hline 7. & Amadi-Ama & 38.480 & 61.520 \\
\hline 8. & Elimgbu & 19.459 & 80.540 \\
\hline 9. & Rumuesara & 38.480 & 61.520 \\
\hline 10. & Mgbuoshimini & 11.299 & 88.70 \\
\hline 11. & Mgbuodohia & 9.581 & 90.490 \\
\hline 12. & GRA & 38.480 & 61.520 \\
\hline
\end{tabular}


Table 6 Values of $\left(\mathrm{HCO}_{3}+\mathrm{CO}_{3}\right)$ and of $\left(\mathrm{Cl}+\mathrm{SO}_{4}\right)$ as percentages of all Anions for Borehole Samples

\begin{tabular}{|c|c|c|c|}
\hline & $\begin{array}{lll} & \text { Parameter } \\
\end{array}$ & $\mathrm{HCO}_{3}+\mathrm{CO}_{3}$ & $\mathrm{Cl}+\mathrm{SO}_{4}$ \\
\hline 1. & Engle Island Eagle & 16.123 & 83.877 \\
\hline 2. & Boro Park & 39.346 & 60.654 \\
\hline 3. & Rumuola & 56.354 & 43.646 \\
\hline 4. & Moscow Road & 39.248 & 60.752 \\
\hline 5. & Trans-Amadi & 24.453 & 75.547 \\
\hline 6. & Olympia & 30.454 & 69.549 \\
\hline 7. & Diobu & 39.452 & 60.566 \\
\hline 8. & Rumukurushi & 38.019 & 61.981 \\
\hline 9. & Eagle Eagle Island & 38.575 & 61.425 \\
\hline 10. & Old GRA & 39.544 & 60.456 \\
\hline 11. & Borokiri $^{(P)}$ & 6.832 & 93.168 \\
\hline 12. & Borokiri & 36.068 & 63.932 \\
\hline 13. & Amadi-Ama $^{(P)}$ & 38.109 & 61.891 \\
\hline 14. & Mgbuoshimini $^{(P)}$ & 51.241 & 48.759 \\
\hline 15. & Iriebe & 54.423 & 45.576 \\
\hline 16. & $\mathrm{GRA}^{(\mathrm{P})}$ & 44.912 & 55.088 \\
\hline
\end{tabular}

Table 7 Classification of Hydrochemical Facies.

Percentage of Constituents, epm

\begin{tabular}{|c|c|c|c|c|}
\hline & $\mathrm{Ca}+\mathrm{Mg}$ & $\mathrm{Na}+\mathrm{K}$ & $\mathrm{HCO}_{3}+\mathrm{CO}_{3}$ & $\mathrm{Cl}+\mathrm{SO}_{4}$ \\
\hline \multicolumn{5}{|l|}{ Cation facies: } \\
\hline Calcium-Magnesium & $90-100$ & $0<10$ & & \\
\hline Calcium-Sodium & $50-90$ & $10<50$ & & \\
\hline Sodium-Calcium & $10-50$ & $50<90$ & & \\
\hline Sodium-potasium & $0-10$ & $90-100$ & & \\
\hline \multicolumn{5}{|l|}{ Anion facies: } \\
\hline Bicarbonate & & & $90-100$ & $0<10$ \\
\hline Bicarbonate-Chloride-Sulphate & & & $50-90$ & $10<50$ \\
\hline Chloride-Sulphate-Bicarbonate & & & $10-50$ & $50<90$ \\
\hline Chloride-Sulphate & & & $0-10$ & $90-100$ \\
\hline
\end{tabular}

(Back, 1966)

dissociation of $\mathrm{HCO}_{3}{ }^{-}$. According to Davis and DeWriest (1966) the process is only effective largely above a pH of 8.2 below this $\mathrm{pH}$, most of the $\mathrm{CO}_{3}{ }^{2-}$ add $\mathrm{H}^{+}$to become $\mathrm{HCO}_{3}$ :

$$
\mathrm{H}^{+}+\mathrm{CO}_{3}^{2-}=\mathrm{HCO}_{3}^{-} \text {. }
$$

In fact, the dependence of individual $\mathrm{CO}_{2}$ forms on $\mathrm{pH}$ is shown in Table 8.

Table 8: Dependence of Individual $\mathrm{CO}_{2}$ forms on $\mathrm{pH}$

\begin{tabular}{llllllllll}
\hline & \multicolumn{8}{c}{$\% \mathrm{CO}_{2}$ at $\mathbf{~ p H}$} \\
\cline { 2 - 10 } $\mathrm{CO}_{2}$ forms & 4 & 5 & 6 & 7 & 8 & 8.3 & 9 & 10 & 11 \\
Free & 99.5 & 95.4 & 67.7 & 17.3 & 2.0 & 1.0 & 0.2 & - & - \\
Bicarbonate & 0.5 & 4.6 & 32.2 & 82.7 & 97.4 & 97.8 & 94.1 & 62.5 & 14.3 \\
Carbonate & - & - & - & - & 0.6 & 1.2 & 5.7 & 37.5 & 85.7 \\
\hline
\end{tabular}

(UNESCO/WHO, 1978)

It is therefore not surprising that $\mathrm{CO}_{3}{ }^{2-}$ is completely undetected in all the samples. The occurrence of $\mathrm{HCO}_{3}{ }^{-}$in all samples (Tables 1 and 2) is favoured by the $\mathrm{pH}$ conditions of the groundwater system.

In the shallow groundwater environment (the wells), $\mathrm{HCO}_{3}{ }^{-}$values range from $12.2 \mathrm{mg} / \mathrm{l}$ to $36.6 \mathrm{mg} / \mathrm{l}$ with an average of $15.25 \mathrm{mg} / \mathrm{l}$ while the range in the
THE USE OF ANION GEOCHEMISTRY IN MAPPING GROUNDWATI

It is known that below $\mathrm{pH}$ of $8.2, \mathrm{HCO}_{3}{ }^{-}$forms $\mathrm{CO}_{3}{ }^{2-}$ by addition of $\mathrm{H}^{+}$. The maximum $\mathrm{pH}$ value recorded in this research for the shallow and deep water environments are 6.30 and 6.14 respectively (Tables 1 \& 2) and this favours the occurrence of the bicarbonate ion. The relatively high values of $\mathrm{Cl}^{-}$in all samples is tied to the fact that irrespective of its source, $\mathrm{Cl}^{-}$is 
conservative. It does not react easily with aquifer materials and tends to be closely associated with water molecules (Mercado, 1985). These qualities preclude $\mathrm{Cl}^{-}$from being quickly removed from solution and enhances its relatively easy occurrence in groundwater. In the shallow water environment (Table 1) the ion ranges from $11.332 \mathrm{mg} / \mathrm{l}$ to $121.905 \mathrm{mg} / \mathrm{l}$ with an average of $41.22 \mathrm{mg} / \mathrm{l}$. The respective values in the deep water environment (Table 2) are 5.490 to 72.306 with an average of $17.037 \mathrm{mg} / \mathrm{l}$. It is obvious that the absence of some ions and the varied concentration levels of others should affect the types and number of mappable facies in groundwater systems.

\section{Anion Facies in the Groundwaters}

The percentage of anions concentration in well samples (Table 5) and in borehole samples (Table 6) when matched with the guidelines in the right hand column of Table 7 , resulted in the following groundwater anion facies as presented in Tables 9 and 10 respectively. Both tables show that there is a clear dominance of the $\mathrm{Cl}-\mathrm{SO}_{4}{ }_{4}-\mathrm{HCO}_{3}$ facies over others. Over 80 per cent of the wells and 75 percent of the boreholes are dominated by this facies-type. When the facies types are fitted into the anion diamond field of Domenico (1972), as shown in Fig. 3, there is indication of a facies change, for the well water, from $\mathrm{Cl}-\mathrm{SO}_{4}-$ $\mathrm{HCO}_{3}$ type toward the $\mathrm{Cl}-\mathrm{SO}_{4}$ type, (Fig. 4). In the borehole environment, there is also a facies change from the $\mathrm{HCO}_{3}-\mathrm{Cl}-\mathrm{SO}_{4}$ type, again towards the $\mathrm{Cl}-$ $\mathrm{SO}_{4}$ type as shown in Fig. 5. Chebotarev (1955), using anion species only, develops his well-known sequence which states that all groundwaters tend to evolve chemically towards the composition of seawater, an evolution which according to him is normally accompanied by the regional changes in dominant anion species:

Travel along flow path

$\mathrm{HCO}_{3} \rightarrow \mathrm{HCO}_{3}+\mathrm{SO}_{4}{ }^{2-} \rightarrow \mathrm{SO}_{4}{ }^{2-}+\mathrm{HCO}_{3}{ }^{-} \rightarrow \mathrm{SO}_{4}+\mathrm{Cl} \rightarrow \mathrm{Cl}^{-}+\mathrm{SO}_{4}{ }^{2-} \rightarrow \mathrm{Cl}^{-}$

Increasing age

Table 9 Hydrochemical Facies in Wells

\begin{tabular}{|c|c|}
\hline Location & Hydrochemical Facies \\
\hline $\begin{array}{l}\text { Eagle Island } \\
\text { Rumuosi } \\
\text { Rumuolumeni }^{(s)} \\
\text { Rumuolumeni }^{\text {(d) }} \\
\text { Choba } \\
\text { Borokiri } \\
\text { Amadi-Ama } \\
\text { Elimgbu } \\
\text { Rumuesara } \\
\text { Mgbuosimini } \\
\text { Mgbuodohia } \\
\text { GRA }\end{array}$ & $\begin{array}{l}\text { chloride - sulphate - bicarbonate } \\
\text { chloride - suphate - bicarbonate } \\
\text { chloride - sulphate - bicarbonate } \\
\text { chloride - sulphate - bicarbonate } \\
\text { chloride - sulphate } \\
\text { chloride - sulphate - bicarbonate } \\
\text { chloride - sulphate - bicarbonate } \\
\text { chloride - sulphate - bicarbonate } \\
\text { chloride - sulphate - bicarbonate } \\
\text { chloride - sulphate - bicarbonate } \\
\text { chloride - sulphate } \\
\text { chloride - sulphate - bicarbonate }\end{array}$ \\
\hline
\end{tabular}


Table 10 Hydrochemical Facies in Boreholes

\begin{tabular}{|c|c|}
\hline Location & Hydrochemical Facies \\
\hline $\begin{array}{l}\text { Eagle Island } \\
\text { Boro Park } \\
\text { Rumuola } \\
\text { Moscow Road } \\
\text { Trans-Amadi } \\
\text { Olympia } \\
\text { Diobu } \\
\text { Rumukoroshe } \\
\text { Eagle Island } \\
{ }^{(P)} \\
\text { Old GRA }^{\text {Borokiri }}{ }^{(P)} \\
\text { Borokiri }_{\text {Amadi - Ama }}{ }^{(P)} \\
\text { Mgbuoshimini }^{(P)} \\
\text { Iriebe }^{(P)} \\
\text { GRA }^{(P)}\end{array}$ & $\begin{array}{l}\text { Chloride - sulphate - bicarbonate } \\
\text { Chloride - sulphate - bicarbonate } \\
\text { Bicarbonate - chloride - sulphate } \\
\text { Chloride - sulphate - bicarbonate } \\
\text { Chloride - sulphate - bicarbonate } \\
\text { Chloride - sulphate - bicarbonate } \\
\text { Chloride - sulphate - bicarbonate } \\
\text { Chloride - sulphate - bicarbonate } \\
\text { Chloride - sulphate - bicarbonate } \\
\text { Chloride - sulphate - bicarbonate } \\
\text { Chloride - sulphate } \\
\text { Chloride - sulphate - bicarbonate } \\
\text { Chloride - sulphate - bicarbonate } \\
\text { Bicarbonate - chloride - sulphate } \\
\text { Bicarbonate - chloride - sulphate } \\
\text { Chloride - sulphate - bicarbonate }\end{array}$ \\
\hline
\end{tabular}

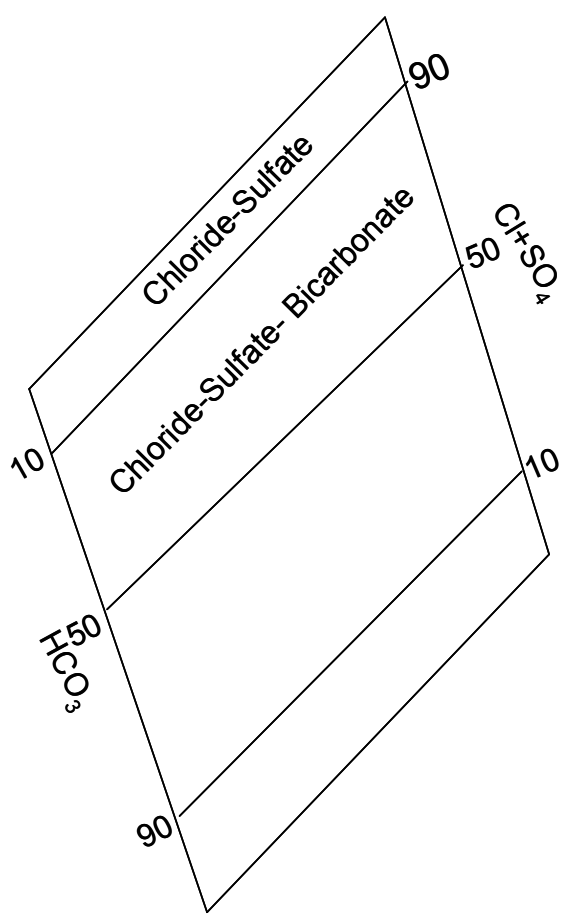

Fig. 4 Anion Facies in shallow groundwater

and Toth (1966b), from investigations in Canada, describes the anion facies development and reports a general tendency for a shift from a pure $\mathrm{HCO}_{3}{ }^{-}$facies in recharge areas to a $\mathrm{SO}_{4}{ }^{2-}$ facies in discharge areas. Within the scope of this work, it is noted that purely $\mathrm{HCO}_{3}{ }^{-}$- water does not exist in the Port Harcourt region. The facies defined in the present work do indicate that the groundwaters are actually tending towards the composition of seawater in some direction (Figs. 4 and 5). This work also reveals that in general, the shallow groundwaters house less number of mappable facies than the deep groundwaters as is obvious from their respective facies:

Hand dug well facies sequences:

$$
\mathrm{Cl}-\mathrm{SO}_{4}^{2}-\mathrm{HCO}_{3} \rightarrow \mathrm{Cl}-\mathrm{SO}_{4}
$$

Borehole facies sequences:

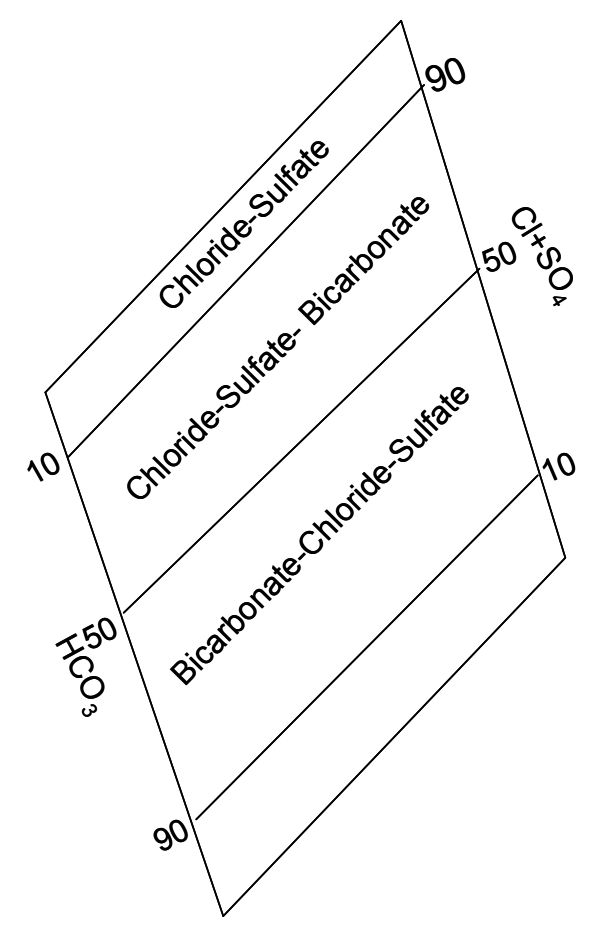

Fig. 5 Anion Facies in deep groundwater environment

$\mathrm{SO}_{4}^{2}$

$$
\mathrm{HCO}_{3}-\mathrm{Cl}-\mathrm{SO}_{4}^{2} \rightarrow \mathrm{Cl}-\mathrm{SO}_{4}^{2}-\mathrm{HCO}_{3} \rightarrow \mathrm{Cl}-
$$

The evolution of these groundwater facies can be reasonably explained by the order of encounter proposed by Freeze and Cherry (1979). This theory briefly states that the order in which groundwaters encounter strata of different mineralogical composition can exert an important control on the final water chemistry. As groundwater flows through strata of different mineralogical composition, the water composition undergoes adjustments caused by the imposition of new mineralogically controlled thermodynamic constraints. Domenico (1972) observes that the type of facies that develops is controlled largely by the mineralogy of the rocks and its distribution is controlled by the flow pattern. 


\section{CONCLUSIONS}

In this work, the use of anion geochemistry has aided in mapping the groundwater facies embedded in the Port Harcourt region of the Niger Delta, Nigeria. Both shallow and deep groundwater environments were accommodated and that informed the use of hand-dug wells and boreholes within the same geographical environment. 28 water samples (12 from wells and 16 from boreholes) were analysed for the relevant anions $\mathrm{Cl}^{-}, \mathrm{SO}_{4}{ }^{2-} \mathrm{HCO}_{3}{ }^{-}$and $\mathrm{CO}_{3}{ }^{2-}$ using standard equipment. The concentration levels of each ion have been discussed and related to the environmental controls on their availability. The result of the analyses show that the groundwater system of the Port Harcourt region is home to three anion facies: $\mathrm{Cl}-\mathrm{SO}_{4}$, the $\mathrm{Cl}-\mathrm{SO}_{4}-$ $\mathrm{HCO}_{3}$ and the $\mathrm{HCO}_{3}-\mathrm{Cl}-\mathrm{SO}_{4}$. Over $80 \%$ of the wells and over $75 \%$ of the boreholes, house the $\mathrm{Cl}-\mathrm{SO}_{4}$ $\mathrm{HCO}_{3}$ facies. The paper finally draws three conclusions that:

$$
\begin{aligned}
& \text { The shallow groundwater environment } \\
& \text { embedded less number of mappable } \\
& \text { facies than the deep groundwater } \\
& \text { environment. } \\
& \text { the existence of different groundwater } \\
& \text { facies is an evidence that groundwater } \\
& \text { encounters strata of different } \\
& \text { mineralogical compositions along its } \\
& \text { flow path and that } \\
& \text { The facies sequences mapped are } \\
& \text { tending towards the composition of } \\
& \text { seawater. }
\end{aligned}
$$

However, the mapped facies sequences and the tendency towards the seawater composition must be viewed, like many others in the geological sciences, in terms of scale and with the normal provisions for interruption and incompletion.

\section{ACKNOWLEDGEMENT}

Our primary acknowledgements are to the imaginative and creative scientists of many nations, who, over the past several decades, have shaped and reshaped the ideas of hydrochemical facies as we now know them. We are grateful to the Shell Petroleum Development Company (Nig.) Ltd, for the sponsorship of the analysis of our water samples.

\section{REFERENCES}

Abibo P.I.T., 1988 Problems of Rural Water Supply in Nigeria: Case Studies from Rivers State. Water Resources (NAH) 1(1) September. 30-36.

Akujieze C. N., S. J. L. Coker and G.E. Oteze, 2003 Groundwater in Nigeria - a millennium experience - distribution, practice, problems and solutions. Hydrogeology Journal 11(2) April, 259-274.

Amadi, P.A.; C.O. Ofoegbu and T. Morrison, 1989. Hydrogeochemical Assessment of Groundwater Quality in Parts of the Niger Delta, Nigeria. Environ Geol. Water Sci. Vol. 14, No.3. pp 195202.

Amajor L.C. 1991 Aquifers in the Benin Formation (Miocene - Recent), Eastern Niger Delta,
Nigeria: Lithostratigraphy, Hydraulics, and Water Quality Environ. Geol. Water Sci. 17(2) 85-101.

Back W., 1966 Hydrochemical facies and groundwater flow patterns in northern part of Atlantic Coastal Plains, US Geol. Surv. Profess. Papers, 498-A

Back W. and Hanshaw B., 1965 Chemical Geohydrology. In: V.T. Chow (ed.) Advances in Hydroscience, Academic Press Inc., New York. 2 pp 49-109.

Chebotarev I. I., 1955 Metamorphism of natural waters in the crust of weathering. Geochim. Cosmochim. Acta. 8 pp 22-88, 137 - 170 and $198-212$.

Domenico P. A., 1972 Concepts and models in groundwater hydrology. McGraw-Hill Book Company, New York, pp 288-293.

Etu-Efeotor J. O., 1981 Preliminary Hydrogeo-chemical Investigations of Subsurface Waters in parts of the Niger Delta J. Min. Geo. 18(1) 103 - 105.

Freeze R. A. and Cherry J.A., 1979 Groundwater. New Jersey, Prentice-Hall Inc., pp 247 - 252

Nedeco (Netherlands Engineering Consultants), 1959 Report on Niger Delta Development, 57 pp.

Piper A. M. 1944 A graphic procedure in the geochemical interpretation of water analyses. Trans. Amer. Geophys. Union. 25 pp $914-923$.

Toth J., 1966b Groundwater geology, movement, chemistry and resources near Olds, Alberta. Res. Council Alberta (Can), Geol. Div., Bull., 17.

UNESCO/WHO 1978 Water Quality Surveys. Studies and Reports in Hydrology 23, pp62-78.

\section{FIGURE CAPTIONS}

Figure $1 \quad$ Location map showing positions of wells and boreholes

Figure $2 \quad$ Characteristic areas

Fiqure $3 \quad$ Nomenclature for hydrochemical facies

166

P. AMAl

Figure 5

Anion facies in boreholes 
